\title{
Does a Spouse Slow You Down?: Marriage and Graduate Student Outcomes*
}

\author{
Joseph Price \\ Department of Economics \\ Cornell University
}

\begin{abstract}
Using data on 11,000 graduate students from 100 departments over a 20 year period, I test whether graduate student outcomes (graduation rates, time to degree, publication success, and initial job placement) differ based on a student's gender and marital status. I find that married men have better outcomes across every measure than single men. Married women do no worse than single women on any measure and actually have more publishing success and complete their degree in less time. The outcomes of cohabiting students generally fall between those of single and married students.
\end{abstract}

"Contact information: jpp34@ cornell.edu

This paper has benefited from comments from Ron Ehrenberg, Jeff Groen, George Jakubson, Claire Kamp Dush, Francesca Molinari, and participants at the Mellon Foundation GEI conference and Cornell's TWIP seminar. 
Recent demographic trends have shown rapid rise in the age of first marriage (Schoen and Weinick 1993, Cherlin 2005), especially among the highly educated (Goldstein and Kenney 2001). One explanation for the decision to delay marriage among those pursuing a post-gradate degree is that marriage (or having a spouse) will be a hindrance to successful work in graduate school. Even if this is not true for a particular student, he or she may fear the stereotypes that faculty might have towards students who are married and/or have children (Ferreira 2003).

This paper uses a dataset of 11,000 graduate students from 100 departments over a 20 year period to explore whether graduate student outcomes (graduation rates, time to degree, publications, job placement) differ based on a student's gender and whether they were married when they entered graduate school. The dataset was collected by the Andrew W. Mellon Foundation as part of their Graduate Education Initiative (GEI). The data includes information on each student's GRE scores, yearly progress towards his or her degree, and whether they had a masters degree prior to enrolling, all of which come from administrative data. In addition, survey data provides the student's age, marital status, and presence of children at the start and end of graduate school.

Of the students in my sample, 9\% were still enrolled in their Ph.D program at the time the data collection stopped. Thus, for this group, I do not observe whether they ultimately graduate nor how long it takes them to complete their degree. In order to include these students in my estimation strategy, I use a competing-risk duration model that estimates the probability of either dropping out or graduating (the two "risks" students face) conditional on having survived a certain number of years. I use these 
estimated transition probabilities to simulate the difference in outcomes between students based on their gender and marital status.

For this study, married students are defined as those students who were married at the start of graduate school. The data does not include the date of marriage but rather whether or not the student was married at both the point of entry to and exit from graduate school. It is important to note that not everyone who starts graduate school single stays single (32\% of men and $31 \%$ of women marry during graduate school) and not everyone who starts married stays married (7.4\% of men and $12.1 \%$ of women divorce during graduate school). As a result, any positive impact that we find for marriage will understate the true magnitude of the difference. However, using information on whether a student married during graduate school would lead us to faulty conclusions due to reverse casuality, since students who are in graduate school longer are more likely to marry while in graduate school.

While this paper does not model directly the impact of having a child on graduate student outcomes, the majority of students who are married at the start of graduate school have children before leaving (58\% of married men and $51 \%$ of married women compared to $9 \%$ of single men and women and $19 \%$ of cohabiting men and $17 \%$ of cohabiting women). Thus, for many students, we can think of marriage and parenthood as being a package that will be evaluated jointly in this paper.

Finally, while this paper does not estimate the casual impact of marriage (since students are free to select their marital status and there is no clear policy lever or natural variation to use as an instrument for marriage). Thus the primary question in this paper is 
whether married students do as well as or better than single students, conditional on having enrolled in graduate school.

\section{BACKGROUND}

There has been considerable research devoted to documenting and understanding gender differences in graduate student outcomes. Bowen and Rudenstine (1992) find that while the gender gap in completion rates disappeared at smaller programs during the 1970's, the gender gap still persisted at larger programs. Seagram, Gould, and Pyke (1998) find no evidence of gender differences in time to degree (conditional on completion) but do find that men were more satisfied with their doctoral education overall. Ferreira (2003) finds higher attrition rates among female graduate students which is in part due to the lower quality of advisor interaction they report. Other studies that report gender differences in time to degree, with female students requiring more time, include Abedi and Benkin (1987), Tuckman et al. (1990), and Yeates (1991). Understanding gender differences in graduate student outcomes is important because it affects the gender mix of the nation's future faculty which can in turn affect the educational outcomes of female students (Meinholdt and Murray 1999).

Solmon (1976) provides a review of many of the issues related to gender and graduate student outcomes. He explains that marriage might affect men and women differently because marriage places different demands on the time and mobility of men and women. For example, Patterson and Sells (1973) show that single graduate students of either gender spend about equal time doing household chores. However, married female graduate students spend more time doing chores than the single students while 
married male students actually spend less time doing chores than single students. Another example provided by Cross (1974) is that women are more likely to drop-out to accompany a spouse to a new location than vice versa. These older studies would appear to indicate that marriage would negatively affect female students. Social norms with regards to balance of duties within marriage have changed since the 1970's (Amato et al. 2003), and so it is possible that these earlier results no longer apply to the situation of the 1980-90's, which is the period of this study. However, these earlier findings likely continue to influence beliefs about the ability of married women to succeed in graduate school.

Recent research, in areas unrelated to higher education, provide explanations for the link between marriage and graduate student outcomes. ${ }^{1}$ These studies show that married individuals are more productive (Korenman and Neumark 1991), engage in less risky behaviors (Umberson 1987), are healthier (Williams and Umberson 2004), and experience higher levels of well-being (Dush and Amato 2005). The effects of marriage are usually smaller for women since the behavioral changes that accompany marriage are smaller for women than for men (Waite 1995).

Past research on the relationship between marital status and student outcomes has been limited by either the availability of data that contains measures of both the student's marital status and student outcomes or by a limited sample size that does not lend itself well to statistical analysis. The closest attempt to do a large-scale examination of the issue is work by Feldman (1973) which uses a survey conducted by the Carnegie Commission on Higher Education of 33,000 graduate and professional school students in the United States. Feldman found that married men were the most likely to present a

\footnotetext{
${ }^{1}$ Good summaries are provided by Waite (1995) and Akerlof (1998).
} 
paper, publish an article, and the least likely to report that emotional strain may force them out of graduate school. The major differences he finds between single and married female students, is that married female students have less social interaction with fellow students and are more likely to state that their career will take second place to family obligations. The major limitation of the Carnegie survey is that it lacks a measure of student outcomes, such as whether the student graduated and his or her time to degree.

\section{DATA}

The data for this paper was provided by the Andrew W. Mellon Foundation as part of an analysis of its Graduate Education Initiative (GEI). The institutional dataset includes information on 22,607 students from 100 departments spanning 10 fields of study and 13 institutions. ${ }^{2}$ The sample includes $18 \%$ of all Ph.D's awarded nationally in these fields from 1980 to 1991 and 50\% of Ph.D's awarded at top 10 departments (based on NRC rankings) in these fields. This institutional data was collected for ten years prior to the start of the program, creating a sample that includes 108,000 student-year observations from the entering cohorts of 1982 to 2001 . This data includes information on each student's gender, race, GRE verbal and quantitative score, field of study, and institution. This data also includes the student's entry and exit date and whether they left with a degree or attrited.

In addition to collecting data from the graduate departments, the Mellon Foundation also administered an extensive survey directly to all of the students who

\footnotetext{
${ }^{2}$ The fields included in the data are anthropology, art history, classics, comparative literature, English, history, music, philosophy, political science, and religion. The institutions include Chicago, Columbia, Cornell, Harvard, Michigan, North Carolina, Pennsylvania, Princeton, Stanford, UC Berkeley, UC San Diego, UCLA, and Yale
} 
entered one of the participating departments between 1982 and 1996. The survey included questions about the student's age, marital status, publications, and characteristics of their first job. The survey was completed by 12,289 students ( $74 \%$ response rate). Of those who took the survey, nearly every respondent answered the questions about age and marital status. The 64 survey responses that did not include information on the student's age or marital status were removed from the sample. I also excluded the 43 students who completed their degree in 3 or fewer years as well as the 747 students who were still enrolled eleven or more years after starting their degree. These restrictions focus the analysis on the typical student and leave a final sample of 11,435 .

The survey did not ask the student for a marital history or when their current marriage started. Rather, it asked for the student's marital status when he or she entered or exited (through attrition or graduation) the doctoral program. While most of the analysis will focus on the married/single dichotomy, respondents were able to report whether they were living with a domestic partner (an issue I'll address later in the paper).

Ideally we would like to know if students who marry during graduate school have different outcomes than those who stay single. However, students who stay in school longer are more likely to get married while in school. This would cause us to misattribute longer time to degree to marriage. The data also provides no information on when students marry, so there would be no way to distinguish between a student who married shortly after entering graduate school from one who married shortly before completing their degree. As a result, the analysis that follows will be comparing the outcomes of students who were married at the start of graduate school to those who were not. 
Table 1 provides summary statistics by gender and marital status. This table shows some of the differences between the single and married students. On average, the married students are 5 years older and have lower undergraduate GPA's and GRE verbal scores. Failing to account for these differences would bias the results against finding a positive impact of marriage. All of these differences are controlled for in the models used in the following section.

\section{METHODS}

The two outcomes of primary interest in this paper are the probability that a student completes her degree and the number of years it takes complete. To look at graduation rates, I use a competing-risk duration model in which I estimate the probability of either graduating or dropping out (the two "risks" students face) conditional on having survived up to that point. ${ }^{3}$ At the end of each year, one of three outcomes has occurred for each student: (1) they have graduated by that point, (2) they have dropped out by that point, or (3) they are still pursuing a degree. These three outcomes are used as the dependent variables in a multinomial logit model. The control variables include the student's gender, marital status, GRE verbal and quantitative score, race, age, whether he or she had a masters degree prior to entering graduate school and indicators for the student's field and institution. For attrition, I look at years 1-11 and for graduation I look at years $4-11$.

The coefficients from the multinomial logit model are used to predict what the outcomes would have been for the entire sample if all the students had been of a certain

\footnotetext{
${ }^{3}$ This approach is used by Ehrenberg and Mavros (1995) to examine the impact of financial aid on student outcomes and by Groen et al. (2005) to evaluate the impact of the GEI. For additional background on competing-risk duration models see Han and Hausman (1990).
} 
group, say single men. Predictions are calculated for each of the four gender/martial status combinations. This approach is similar to a conventional hazard model with the advantage that it allows us to model the fact that in each period students are at risk of two competing hazards (graduating or dropping out). As with the hazard model, the major advantage of this model is that it allows us to use information for all students in the sample even if we have not yet observed whether or not the ultimately graduate.

In order to estimate differences in the average time to degree, the graduation rate for each year in school is calculated by differencing the cumulative probabilities. Let $\mathrm{G}_{\mathrm{it}}$ indicate the fraction of students in group $i$ that have graduated by time $t$. The fraction of students that graduate in each year in school is given by $g_{i t}=G_{i t}-G_{i t-1}$. Using the graduation rate each year, the average time to degree of each group is calculated using:

$$
T T D_{i}=\sum_{t=4}^{11}\left(g_{i t} \cdot t\right)
$$

where $\mathrm{t}$ indicates the number of years it took the student to complete his or her $\mathrm{PhD}$. This measure is simply a weighted average of time to degree across all of the students, where the weights are determined by the fraction of students who finished in that amount of time.

As an additional check of the methods described above, I also estimate the differences in graduation rates and time to degree using traditional methods of OLS and logit regression. In each case, I include controls for the year that the student entered graduate school to account for the amount of time that was available to the student to graduate. This method also provides a simple way to look a wider range of outcomes such as publishing success and the student's initial job placement. 


\section{RESULTS}

Table 2 contains the simulated probability of graduating or dropping out by a certain year for each group. The numbers from this table are plotted for male and female students separately in figures 1 and 2 . These figures show visually that there are large differences by marital status in the cumulative graduation and attrition rates for male students, but almost no noticeable difference for female students.

Figure 1 shows that for male students the difference in the cumulative graduation rate widens during years four through seven and then narrows over years eight through eleven. The results in table 2 show that married male students are $75 \%$ more likely to complete their degree by the $4^{\text {th }}$ year and $66 \%, 39 \%$, and $29 \%$ more likely than single male students to complete their degree by the years 5,6 , and 7 respectively. The difference for female students is $25 \%, 32 \%, 17 \%$, and $9 \%$ for years $4,5,6$, and 7 respectively. The difference for female students disappears after year 7 but persists through all years for male students.

Table 3 summarizes the results of table 2 by averaging the difference in the cumulative graduation rate between each set of groups over years 4 through 11 . The same is done for the cumulative attrition rates for years 1 through 11 . The results are replicated using 1,000 bootstrap samples to test for the statistical significance of these differences. The $90 \%$ confidence interval of each estimate is providing in brackets under each estimate.

These results show that the average difference in cumulative probability of graduating between single and married male students is 3.4 percentage points (or 6\%) and is statistically significant. This difference is smaller than the raw difference of 6.1 
percentage points that we observed in table 1 (65.3 vs. 59.2), indicating that some of the observable characteristics of married male students that I control for account for some of the raw difference. The average difference for female students is 0.9 percentage points and not statistically significant.

The $3^{\text {rd }}$ column of table 3 shows the difference in time to degree between each gender/marital status group. The results indicate that married men complete their degree .32 years quicker (a 5\% difference) than single male students, married female students complete their degree about .21 years quicker (a $3 \%$ difference) than single female students, and single male students complete their degree .12 years quicker (a $2 \%$ difference) than single female students.

Table 4 provides an additional check of the results of the competing risk model by estimating the gender and marital status differences using more traditional methods of OLS and logit regression. The results reported when using logit regression are the average marginal effect which are calculated by estimating the marginal effect on each individual and then average this affect across the sample. The results show that married males students are 5.2 percentage points (or $9 \%$ ) more likely to graduate than a single male student. This is just slightly less than the estimate of 5.7 percentage points obtained using the competing risk model. In terms of time to degree, married men completed their degree about .357 years quicker (conditional on graduating) than male students who were not married at the start of graduate school. This represents a slightly larger effect than the .319 years obtained through the competing risk model

For women, the point estimates obtained in the logit regression for whether or not the student graduates are nearly identical to the results of the competing risk model (1.6 
percentage points) though this difference is no longer significant. The difference in time to degree is slightly smaller (.184 years compared to .210 years) but significant in both cases. This confirms the general pattern that female students who are married are not any less likely to graduate and actually complete their degree quicker than single female students.

In addition to wanting to graduate and do so in a timely manner, students also care about the type of job that they receive upon leaving graduate school and the success they experience in publishing their research. The results in table 4 show that married male students are 4 percentage points more likely to publish during publish while in graduate school, have .17 more publications, and are 8.4 percentage points more likely to obtain a tenure track position within 6 months of graduating, compared to single male students. Married women are also more likely to publish (7.9 percentage points) and have more publications during graduate school (.193 more) though there is no significant difference in their probability of getting a tenure track position within 6 months of graduating. It is interesting to note that relative to single men, both single and married women are more likely to get a tenure track position (4.2 and 5.9 percentage points more respectively).

\section{OTHER ISSUES}

As with most studies on the impact of marriage, it is possible that these results merely reflect a selection effect in which students who chose to marry have unobservable characteristics that make them more persistent and help them graduate quicker than single students. Korenman and Neumark (1991) address this issue in their study of the impact of marriage on worker productivity. They compare estimates from cross-section and fixed- 
effects models and find that less than $20 \%$ of the difference in wages between married men and single men can be attributed to a selection effect. The methodology they use depends on having an outcome variable that varies over time for the individual, which is the not the case in this paper, but it is possible that the split between fraction of the marriage effect that is due to selection is similar.

Whether selection explains the results in this paper depends on the assumption that higher quality students are selecting themselves into marriage. However, as shown in table 1, married students actually have much lower GRE scores (20 points lower on the verbal section and 30 points lower on quantitative section) which might be the result that they are generally older (and presumably have been out of school longer)

However, even without clear evidence of a casual interpretation of the estimates in this paper, the results still show that marital status can serve as a potential signal of the ability of a student to do well in graduate school. In the past it has been thought that married women would be limited in their ability to be successful in graduate school, and it is possible that this accounts in part for the rising age of first marriage for women with graduate degrees. The results of this paper show that married women are just as likely to complete their Ph.D as single women, conditional on enrolling in a graduate program.

Another consideration is that the measure used in this paper was whether or not the student was married. While $21 \%$ of men were married when they entered graduate school, and an additional $9 \%$ had a domestic partner. For women, $18 \%$ were married at the start of graduate school; and an additional $12 \%$ had a domestic partner. If the benefits of having a domestic partner are similar to those of being married than this will bias the results in this paper downward. When I exclude the students with domestic partners from 
the analysis, the gap between the outcomes of married men and of single men widens. This indicates that students with a domestic partner have better outcomes than single students.

I also classify the students with domestic partners with those of the married students into a new distinction of "committed partners". When I redo the analysis with this new classification, the gap between students with committed partners and single students is slightly smaller than the gap of married and non-married students. This indicates that the outcomes of students with a domestic partner are somewhere between single students and married students, though closer to single students than married students.

None of these changes in classification have any change on the size of the gap for women, with one exception. The gap in time to degree shrinks when I either exclude women with domestic partners or reclassify them with the married students. This indicates that women with domestic partners take longer to complete their degree than either single women or married women, after controlling for differences in observable characteristics.

As an additional way of testing the differences based on marriage and cohabitation, I repeat the analysis of table 4, but I include having a domestic partner as an additional category (that is mutually exclusive of being married and being single). The results are shown in appendix table 1 . For men, the outcomes of students with domestic partners generally fall in between that of single students and married students, with the exception of the probability of publishing, in which married and cohabiting students are 
essentially identical. However, the precision of these estimates is such that there are no statistically significant differences between single and cohabiting male students.

For women, graduation rates are essentially identical for all three groups though the point estimates indicate that married women complete their degree faster than both single and cohabiting women. In terms of publishing success, both cohabiting and married women do equally well and generally do better than single women (though this difference is only statistically significant for married women due to the smaller sample size of the cohabiting women).

It is interesting to note the large differences in the probability of obtaining a tenure track job within 6 months of graduating, with married male students 8.6 percentage points more likely to obtain one than single male students and 6.8 percentage points more likely to obtain one than a cohabiting male student. For women, the distinction between the three groups is not significant though the point estimates indicate that women who are single at the start of graduate school are less likely than the other female groups to get a tenure track position (about a 2-3 percentage point difference and not statistically significant), but they are still more likely to get a tenure track position than single men. This is striking given the much higher probability that cohabiting and married women have of having a baby (12 and 38 percentage points greater likelihood relative to single women).

One major limitation of this study is that the survey did not contain any information about the activities of the student's spouse or unmarried partner. This would be an important area of future research since the benefits of marriage may depend on whether or not the student's spouse is also a student. I use the 2000 census $5 \%$ public use 
micro-sample to look at the status of the spouse or unmarried partner of all of the individuals who are enrolled in a graduate or professional degree in one of the eight states that include at least one of the sample institutions. The results in table 5 show that $27 \%$ of married male students have a spouse who is also a student compared to $35 \%$ of men who are living with an unmarried partner. The results also show that $21 \%$ of married female students have a spouse who is also a student compared to $28 \%$ of female students with an unmarried partner. Future research could explore whether the gap in outcomes by marital status differs based on spouse's work or student status.

\section{CONCLUSION}

This paper shows that, after controlling for individual characteristics, students married prior to starting graduate school do not have worse outcomes than single students. Married male students are much more likely to graduate by any given year than single students. The percentage difference in the probability of graduating between single and married male students is positive for all years with the largest differences occurring in years 4 through 7 . In fact, married male students are $75 \%, 66 \%$, and $39 \%$ more likely than single male students to complete their degree by years 4,5 , and 6 respectively. Simulating the time to degree of each group shows that the married male students complete their degrees .32 years quicker than single male students.

Married female students were $25 \%, 32 \%, 17 \%$, and $9 \%$ more likely than single

female students to graduate by years $4,5,6$, and 7 . The difference does not persist after year 7 , and the probability of a female student graduating by year 8-11 is essentially the 
same between the two marital status groups. Married female students completed their degrees .21 years quicker than single female students.

The results also show that married students are more likely to publish during graduate school and have more publications. For men, marriage is also associated with a higher probability of obtaining a tenure track position with six months of graduating. These results indicate that the marriage premium that we observe for men in labor markets (Korenman and Neumark 1991, Loh 1996) are also present in terms of the productivity and placement of graduate students. The results also indicate that for female students there are no major differences in performance during graduate school based on the student's marital status. 


\section{REFERENCES}

Abedi, J. and E. Benkin. 1987. “The Effects of Students' Academic, Financial, and

Demographic Variables on Time to the Doctorate." Research in Higher Education, 27, 3-

14.

Akerlof, G. "Men without Children.” 1998. The Economic Journal, 108: 297-309.

Amato, P., D. Johnson, A. Booth, and S. Rogers. 2003. "Continuity and Change in Marital Quality Between 1980 and 2000.” Journal of Marriage and Family, 65:1-22.

Bowen, W. and N. Rudenstine. 1992. In Pursuit of the PhD. Princeton, NJ: Princeton University Press.

Cherlin, A. 2005. "American Marriage in the Early Twenty-First Century.” Future of Children, 15: 33-55.

Cross, K. P. 1974. “The Woman Student.” In W.T. Furness and A. Graham (eds), Women in Higher Education. Washington DC: American Council on Education.

Dush, C. and P. Amato. 2005. “Consequences of Relationship Status and Quality for Subjective Well-being." Journal of Social and Personal Relationships, 22:607-627, 
Ehrenberg, R. and P. Mavros. 1995. “Do Doctoral Students' Financial Support Patterns Affect Their Times-To-Degree and Completion Probabilities?" The Journal of Human Resources, 30:581-609.

Feldman, S. 1973. "Impediment of Stimulant? Marital Status and Graduate Education." The American Journal of Sociology, 78:982-994.

Ferreira, M. 2003. "Gender Issues Related to Graduate Student Attrition in Two Science Departments." International Journal of Science Education, 25: 969-989.

Goldstein, J. and C. Kenney. "Marriage Delayed or Marriage Forgone? New Cohort Forecasts of First Marriage for U.S. Women.” American Sociological Review, 66: 506$519,2001$.

Han, A. and J. Hausman. 1990. "Flexible Parametric Estimation of Duration and Competing Risk Models.” Journal of Applied Econometrics, 5:1-28.

Groen, J., G. Jakubson, R. Ehrenberg, S. Condie, and A. Liu. 2006. "Program Design and Student Outcomes in Graduate Education." National Bureau of Economic Research working paper no. 12064.

Korenman, S. and D. Neumark. 1991. "Does Marriage Really Make Men More Productive? The Journal of Human Resources, 36: 282-307. 
Loh, E. 1996. "Productivity Differences and the Marriage Wage Premium for White Males." The Journal of Human Resources, 31: 566-589.

Meinholdt, M. and A. Huberman. 1999. "Why Aren't There More Women Engineers?" Journal of Women and Minorities in Science and Engineering, 5:239-263.

Patterson, M. and L. Sells. 1973. "Women Dropouts from Higher Education.” In A.S. Rossi and A. Calderwood, (eds). Academic Women on the Move. New York: Russell Sage Foundation.

Schoen, R. and R. Weinick. 1993. "The Slowing Metabolism of Marriage: Figures from 1988 U.S. Marital Status Life Tables.” Demography, 30: 737-746.

Seagram, B., J. Gould, and S. Pyke. 1998. "An investigation of gender and other variables on time to completion of Doctoral Degrees." Research in Higher Education, 39: 319-335.

Solmon, L. 1976. Male and Female Graduate Students: The Question of Equal Opportunity. New York: Praeger Publishers.

Tuckman, H., S. Coyle, and Y. Bae. 1990. On Time to the Doctorate: A Study of the Increased Time to Complete Doctorates in Science and Engineering. Washington D.C.: National Academy Press. 
Umberson, D. 1987. "Family Status and Health Behaviors: Social Control as a Dimension of Social Integration." Journal of Health and Social Behavior, 28:306-19.

Waite, L. 1995. “Does Marriage Matter?” Demography, 32:483-507.

Williams, K. and D. Umberson. 2004. "Marital Status, Marital Transitions, and Health: A Gendered Life Course Perspective.” Journal of Health and Social Behavior, 45:81-98.

Yeates, M. 1991. Doctoral Graduation Rates in Ontatio Universities. Toronto: Council of Ontario Universities. 
Table 1. Summary statistics by gender and marital status

\section{Demographic}

Age (mean)

Age (median)

Non US citizen

US white

US non-white

Ability and Training

Prior Masters degree

GRE verbal

GRE math

Outcomes

Graduation rate

Attrition rate

Time to Degree

Published during grad school

Number of publications

Tenure track position at 6 months

$\mathbf{N}$

\begin{tabular}{rr|rr}
\multicolumn{2}{c}{ women } & \multicolumn{2}{c}{ men } \\
\hline \multicolumn{1}{c}{ Single } & Married & \multicolumn{1}{c}{ Single } & Married \\
\hline $\mathbf{2 4 . 8}$ & & & \\
$\mathbf{2 4}$ & $\mathbf{2 9 . 8}$ & $\mathbf{2 4 . 8}$ & $\mathbf{2 9 . 3}$ \\
0.100 & 0.104 & $\mathbf{0 . 1 2 6}$ & $\mathbf{0 . 1 6 5}$ \\
0.659 & 0.67 & $\mathbf{0 . 6 5 9}$ & $\mathbf{0 . 6 2 2}$ \\
$\mathbf{0 . 1 4 0}$ & $\mathbf{0 . 1 0 4}$ & 0.106 & 0.098 \\
& & & \\
& & & \\
$\mathbf{0 . 1 9 4}$ & $\mathbf{0 . 3 4 2}$ & $\mathbf{0 . 2 1 6}$ & $\mathbf{0 . 3 8 1}$ \\
$\mathbf{6 7 6 . 3}$ & $\mathbf{6 6 0 . 5}$ & $\mathbf{6 8 0 . 5}$ & $\mathbf{6 6 0 . 3}$ \\
$\mathbf{6 1 6 . 4}$ & $\mathbf{5 8 8 . 4}$ & $\mathbf{6 6 0 . 1}$ & $\mathbf{6 3 3 . 6}$ \\
& & & \\
& & & \\
0.571 & 0.573 & $\mathbf{0 . 5 9 2}$ & $\mathbf{0 . 6 5 3}$ \\
0.348 & 0.341 & $\mathbf{0 . 3 2 6}$ & $\mathbf{0 . 2 9 4}$ \\
6.28 & 6.35 & 6.23 & 6.26 \\
$\mathbf{0 . 2 4 3}$ & $\mathbf{0 . 2 7 5}$ & $\mathbf{0 . 3 0 8}$ & $\mathbf{0 . 3 5 5}$ \\
$\mathbf{0 . 4 6 0}$ & $\mathbf{0 . 5 6 7}$ & $\mathbf{0 . 6 6 1}$ & $\mathbf{0 . 8 7 0}$ \\
0.251 & 0.235 & $\mathbf{0 . 2 3 7}$ & $\mathbf{0 . 3 1 4}$ \\
& & & \\
4,533 & 977 & 4,673 & 1,252
\end{tabular}

Notes: Bolded entries indicates that the difference in means between single and married students of that particular gender are significant at the $95 \%$ level. 
Table 2. Simulated Cumulative Probabilities of Attrition and Graduation by Gender and Marital Status.

\begin{tabular}{r|ccr|ccc}
\multicolumn{1}{l|}{$\begin{array}{l}\text { Graduation } \\
\text { Year in } \\
\text { Program }\end{array}$} & $\begin{array}{c}\text { Married } \\
\text { Women }\end{array}$ & $\begin{array}{c}\text { Single } \\
\text { Women }\end{array}$ & \% Diff & $\begin{array}{c}\text { Married } \\
\text { Men }\end{array}$ & $\begin{array}{c}\text { Single } \\
\text { Men }\end{array}$ & \% Diff \\
\hline 4 & 0.015 & 0.012 & $25.0 \%$ & 0.028 & 0.016 & $\mathbf{7 5 . 0 \%}$ \\
5 & 0.069 & 0.052 & $\mathbf{3 2 . 7 \%}$ & 0.113 & 0.068 & $\mathbf{6 6 . 2 \%}$ \\
6 & 0.171 & 0.146 & $\mathbf{1 7 . 1 \%}$ & 0.245 & 0.176 & $\mathbf{3 9 . 2 \%}$ \\
7 & 0.293 & 0.269 & $\mathbf{8 . 9 \%}$ & 0.405 & 0.313 & $\mathbf{2 9 . 4 \%}$ \\
8 & 0.385 & 0.383 & $0.5 \%$ & 0.501 & 0.420 & $\mathbf{1 9 . 3 \%}$ \\
9 & 0.463 & 0.464 & $-0.2 \%$ & 0.568 & 0.495 & $\mathbf{1 4 . 7 \%}$ \\
10 & 0.519 & 0.518 & $0.2 \%$ & 0.604 & 0.548 & $\mathbf{1 0 . 2 \%}$ \\
11 & 0.548 & 0.553 & $-0.9 \%$ & 0.622 & 0.577 & $\mathbf{7 . 8 \%}$
\end{tabular}

\begin{tabular}{lc|ccr|ccc}
\multicolumn{1}{l|}{$\begin{array}{l}\text { Attrition } \\
\text { Year in } \\
\text { Program }\end{array}$} & & $\begin{array}{c}\text { Married } \\
\text { Women }\end{array}$ & $\begin{array}{c}\text { Single } \\
\text { Women }\end{array}$ & \% Diff & $\begin{array}{c}\text { Married } \\
\text { Men }\end{array}$ & $\begin{array}{c}\text { Single } \\
\text { Men }\end{array}$ & \% Diff \\
\hline & 1 & 0.082 & 0.081 & $1.2 \%$ & 0.062 & 0.094 & $\mathbf{- 3 4 . 0 \%}$ \\
& 2 & 0.133 & 0.137 & $-2.9 \%$ & 0.103 & 0.156 & $\mathbf{- 3 4 . 0 \%}$ \\
& 3 & 0.164 & 0.184 & $\mathbf{- 1 0 . 9 \%}$ & 0.134 & 0.193 & $\mathbf{- 3 0 . 6 \%}$ \\
& 4 & 0.209 & 0.219 & $-4.6 \%$ & 0.178 & 0.233 & $\mathbf{- 2 3 . 6 \%}$ \\
& 5 & 0.238 & 0.245 & $-2.9 \%$ & 0.200 & 0.254 & $\mathbf{- 2 1 . 3 \%}$ \\
& 6 & 0.284 & 0.268 & $6.0 \%$ & 0.225 & 0.277 & $\mathbf{- 1 8 . 8 \%}$ \\
& 7 & 0.305 & 0.293 & $4.1 \%$ & 0.245 & 0.296 & $\mathbf{- 1 7 . 2 \%}$ \\
& 8 & 0.315 & 0.308 & $2.3 \%$ & 0.262 & 0.311 & $\mathbf{- 1 5 . 8 \%}$ \\
& 9 & 0.328 & 0.320 & $2.5 \%$ & 0.28 & 0.321 & $\mathbf{- 1 2 . 8 \%}$ \\
10 & 0.337 & 0.331 & $1.8 \%$ & 0.291 & 0.327 & $\mathbf{- 1 1 . 0 \%}$ \\
11 & 0.346 & 0.339 & $2.1 \%$ & 0.298 & 0.332 & $\mathbf{- 1 0 . 2 \%}$
\end{tabular}

Notes: The value in each cell represents the probability that an individual will have graduated or attrited by the year in program indicated by the row. \% Diff is calculated using (married - single)/single for each gender and represents the percentage difference in the probability that the student has graduated or attrited by that year. Statistical significance of the difference was tested using 1,000 bootstrap repetitions. Those differences significant at the $90 \%$ level are bolded. 
Figure 1. Simulated Cumulative Graduation Rates

\section{Female Students}

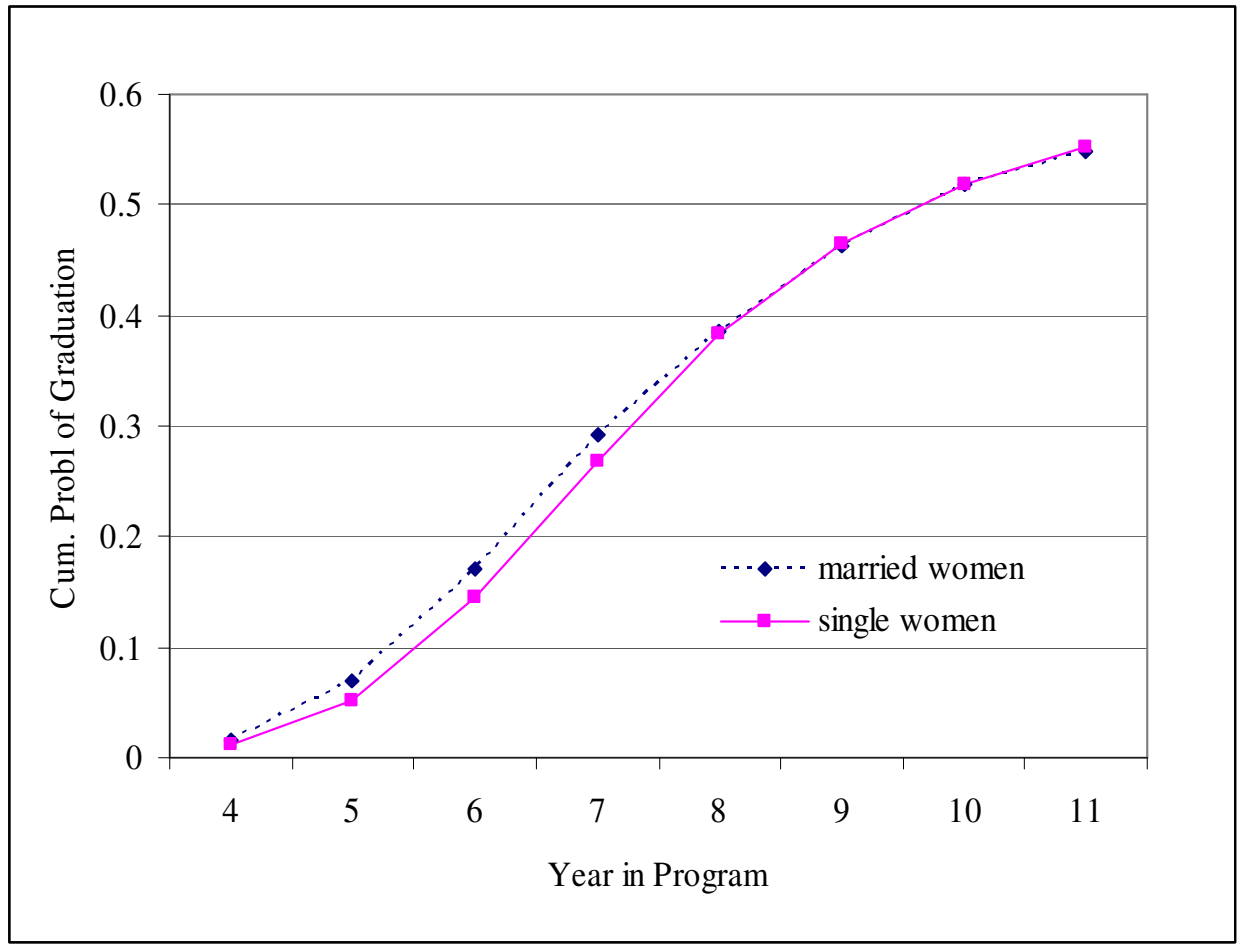

\section{Male Students}

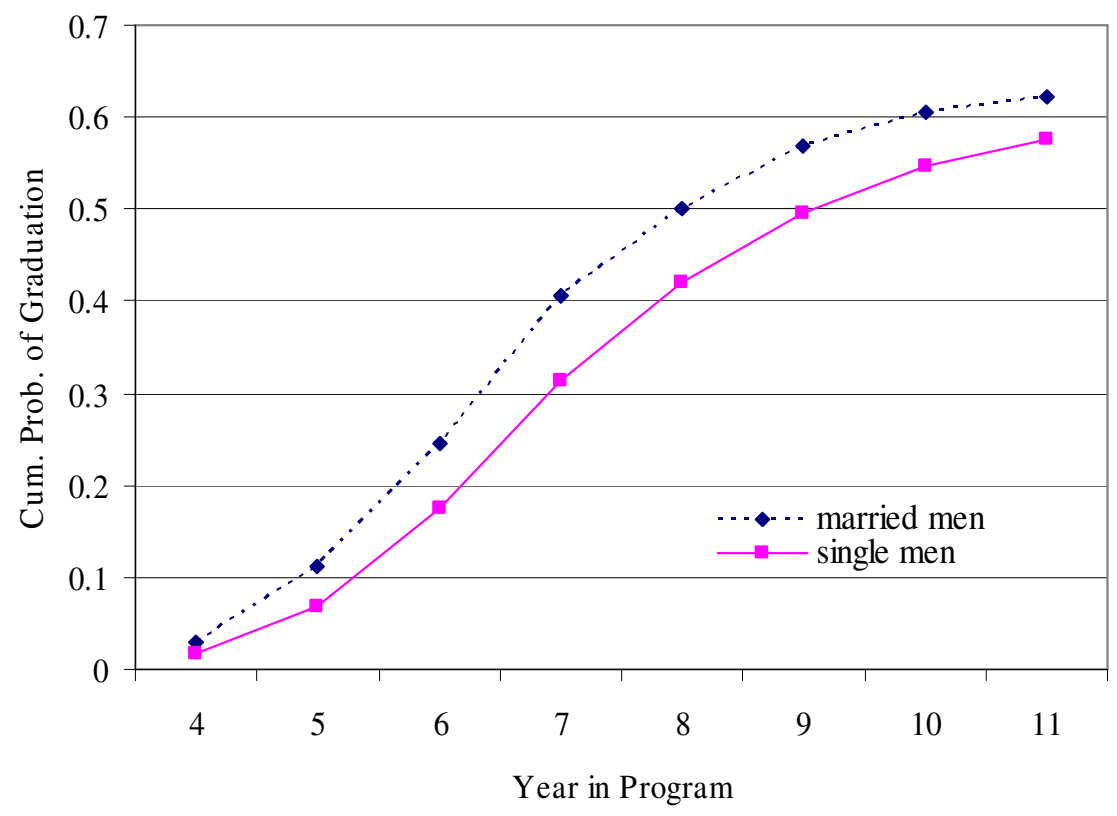


Figure 2. Simulated Cumulative Attrition Rates

\section{Female Students}

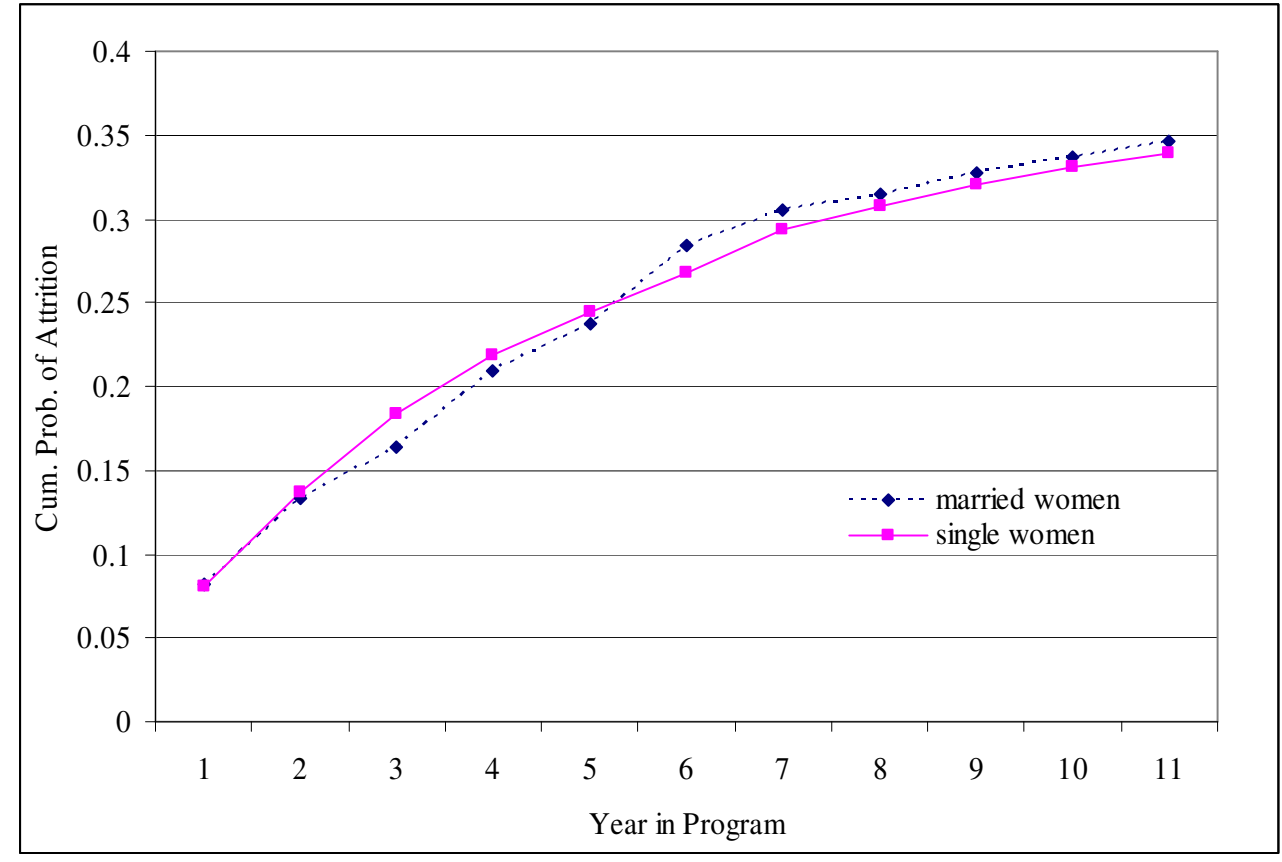

\section{Male Students}

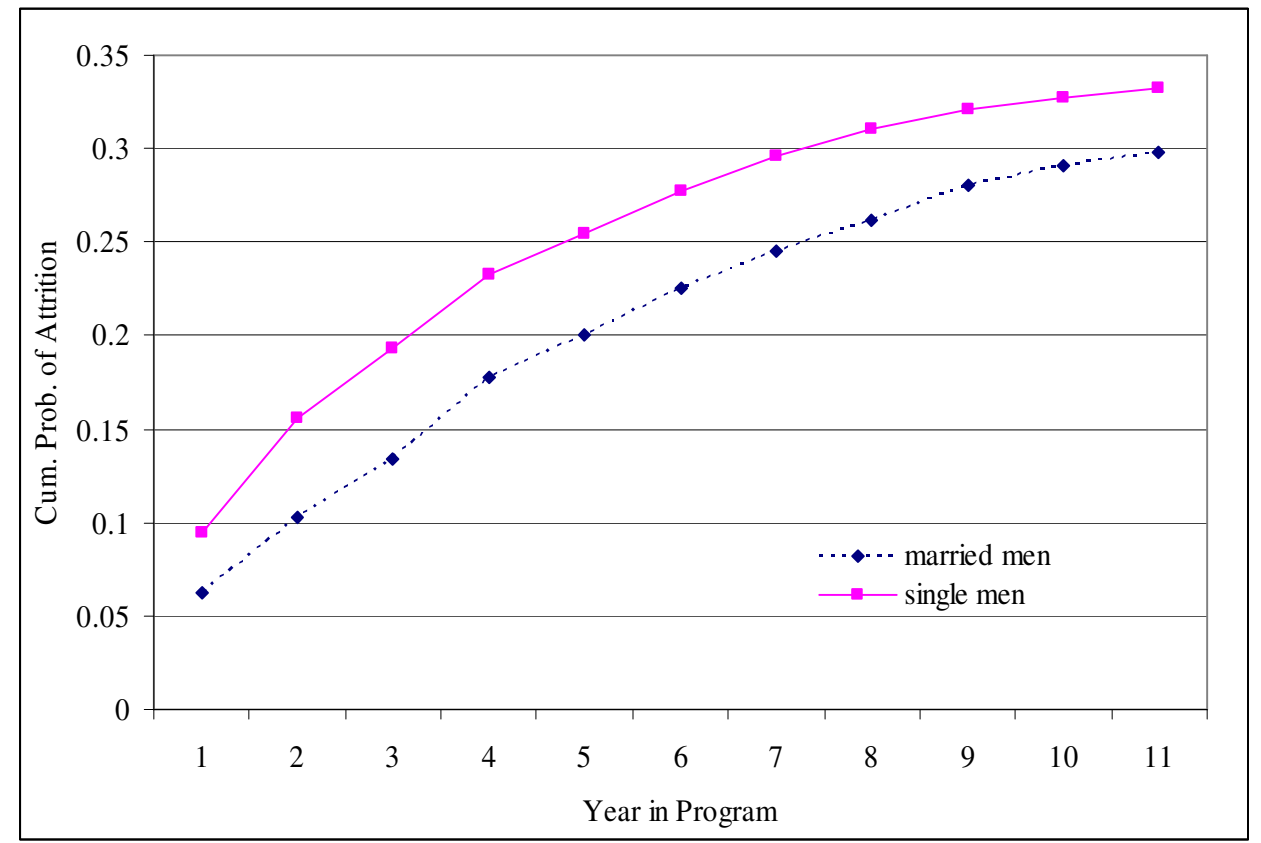


Table 3. Impact of Gender and Marital Status on Student Outcomes

\begin{tabular}{|c|c|c|c|c|}
\hline & $\mathrm{N}$ & Attrition & Graduation & TTD \\
\hline Married Women & 977 & $\begin{array}{c}-0.009 \\
{[-.023, .007]}\end{array}$ & $\begin{array}{c}\mathbf{0 . 0 1 6} \\
{[.002, .030]}\end{array}$ & $\begin{array}{c}\mathbf{- 0 . 2 1 0} \\
{[-.334,-.084]}\end{array}$ \\
\hline Single Women & 4,533 & -- & -- & -- \\
\hline Married Men & 1,252 & $\begin{array}{c}\mathbf{- 0 . 0 3 4} \\
{[-.048,-.020]}\end{array}$ & $\begin{array}{c}\mathbf{0 . 0 5 7} \\
{[.042, .071]}\end{array}$ & $\begin{array}{c}\mathbf{- 0 . 3 1 9} \\
{[-.425,-.211]}\end{array}$ \\
\hline Single Men & 4,673 & -- & -- & -- \\
\hline Single Women & 4,533 & $\begin{array}{c}0.002 \\
{[-.007, .011]}\end{array}$ & $\begin{array}{c}-0.021 \\
{[-.029, .013]}\end{array}$ & $\begin{array}{c}\mathbf{0 . 1 2 2} \\
{[.049, .192]}\end{array}$ \\
\hline Single Men & 4,673 & -- & -- & -- \\
\hline
\end{tabular}

Notes: The $90 \%$ confidence intervals that are shown in brackets were derived by a bootstrap procedure with 1,000 repetitions. The group with dashes is the omitted group in each of the three comparisons. All results and confidence intervals refer to the difference between the two groups. Results significant at the $90 \%$ level are bolded. 
Table 4. Differences in other outcomes by gender and marital status.

\begin{tabular}{|c|c|c|c|c|c|c|}
\hline & $\begin{array}{c}(1) \\
\text { Graduated }\end{array}$ & $\begin{array}{c}(2) \\
\text { Time to degree }\end{array}$ & $\begin{array}{c}\text { (3) } \\
\text { Published while } \\
\text { in school }\end{array}$ & $\begin{array}{c}\text { (4) } \\
\text { Number of } \\
\text { publications }\end{array}$ & $\begin{array}{c}(5) \\
\text { Tenure track job } \\
\text { at } 6 \text { months }\end{array}$ & $\begin{array}{c}\text { (6) } \\
\text { Had a child } \\
\text { before finishing }\end{array}$ \\
\hline $\begin{array}{l}\text { single male }(\mathrm{SM}) \\
\mathrm{N}=4,664\end{array}$ & -- & -- & -- & -- & -- & -- \\
\hline $\begin{array}{l}\text { married male }(\mathrm{MM}) \\
\qquad \mathrm{N}=1,250\end{array}$ & $\begin{array}{c}0.052 * * \\
{[.015]}\end{array}$ & $\begin{array}{c}-0.375 * * \\
{[.064]}\end{array}$ & $\begin{array}{c}0.040 * \\
{[.020]}\end{array}$ & $\begin{array}{c}0.170 * * \\
{[.063]}\end{array}$ & $\begin{array}{c}0.084 * * \\
{[.021]}\end{array}$ & $\begin{array}{c}0.422 * * \\
{[.021]}\end{array}$ \\
\hline $\begin{array}{l}\text { single female (SF) } \\
\qquad \mathrm{N}=4,506\end{array}$ & $\begin{array}{l}-0.011 \\
{[.010]}\end{array}$ & $\begin{array}{c}0.153 * * \\
{[.044]}\end{array}$ & $\begin{array}{c}-0.105^{* *} \\
{[.013]}\end{array}$ & $\begin{array}{c}-0.328 * * \\
{[.043]}\end{array}$ & $\begin{array}{c}0.042 * * \\
{[.014]}\end{array}$ & $\begin{array}{l}-0.001 \\
{[.011]}\end{array}$ \\
\hline $\begin{array}{l}\text { married female }(\mathrm{MF}) \\
\qquad \mathrm{N}=967\end{array}$ & $\begin{array}{l}0.004 \\
{[.017]}\end{array}$ & $\begin{array}{l}-0.043 \\
{[.075]}\end{array}$ & $\begin{array}{l}-0.026 \\
{[.023]}\end{array}$ & $\begin{array}{l}-0.135 \\
{[.074]}\end{array}$ & $\begin{array}{l}0.059 * \\
{[.024]}\end{array}$ & $\begin{array}{c}0.352 * * \\
{[-.023]}\end{array}$ \\
\hline $\mathrm{H}_{0}: \mathrm{SF}=\mathrm{MF}$ & & $* *$ & $* *$ & $* *$ & & $* *$ \\
\hline $\begin{array}{l}\text { estimation } \\
\text { method }\end{array}$ & Logit & OLS & Logit & OLS & Logit & Logit \\
\hline $\mathrm{N}$ & 11,387 & 6,706 & 6,585 & 6,585 & 6,364 & 6,595 \\
\hline
\end{tabular}

Notes: Each estimation includes controls for students characteristics (age, GRE scores, prior masters degree) as well as controls for institution, field, and year the student started graduate school. Columns 2-6 are limited to students who completed their degree. The differences in sample size between columns 2-6 is due to student's not reporting on specific questions within the survey. The results reported in columns in which the estimation method is logit are the average marginal effect of the group relative to single men. 
Table 5. Spouse's work/student status by gender and marital status.

\begin{tabular}{lcccc} 
& \multicolumn{2}{c}{ men } & \multicolumn{2}{c}{ women } \\
& cohabiting & married & cohabiting & married \\
\hline spouse is a student & $35.0 \%$ & $27.2 \%$ & $28.1 \%$ & $20.7 \%$ \\
$\begin{array}{l}\text { spouse works } \\
\text { spouse is not a student }\end{array}$ & $80.2 \%$ & $63.1 \%$ & $84.4 \%$ & $88.2 \%$ \\
or working & $7.8 \%$ & $26.1 \%$ & $6.9 \%$ & $7.8 \%$ \\
\hline $\mathrm{N}$ & 722 & 14,077 & 1,238 & 16,770
\end{tabular}

Notes: Calculations based on 2000 Census 5\% PUMS using the states that include at least one of our sample institutions: CA, CT, IL, MA, MI, NJ, NY, and PA. The sample is restricted to individuals who reported being currently enrolled in graduate or professional school and who had another adult in the household who reported themselves as being the husband/wife or unmarried partner of the enrolled student. 
Appendix Table 1. Differences in other outcomes by gender and marital/cohabitation status.

\begin{tabular}{|c|c|c|c|c|c|c|}
\hline & $\begin{array}{c}(1) \\
\text { Graduated }\end{array}$ & $\begin{array}{c}(2) \\
\text { Time to degree }\end{array}$ & $\begin{array}{c}(3) \\
\text { Published while } \\
\text { in school }\end{array}$ & $\begin{array}{c}\text { (4) } \\
\text { Number of } \\
\text { publications }\end{array}$ & $\begin{array}{c}(5) \\
\text { Tenure track } \\
\text { job at } 6 \text { months }\end{array}$ & $\begin{array}{c}\text { (6) } \\
\text { Had a child } \\
\text { before finishing }\end{array}$ \\
\hline $\begin{array}{l}\text { single male }(\mathrm{SM}) \\
\mathrm{N}=4.106\end{array}$ & -- & -- & -- & -- & -- & -- \\
\hline $\begin{array}{l}\text { cohabiting male }(\mathrm{CM}) \\
\quad \mathrm{N}=558\end{array}$ & $\begin{array}{l}0.032 \\
{[.021]}\end{array}$ & $\begin{array}{l}-0.068 \\
{[.090]}\end{array}$ & $\begin{array}{l}0.053 \\
{[.028]}\end{array}$ & $\begin{array}{l}0.139 \\
{[.088]}\end{array}$ & $\begin{array}{l}0.018 \\
{[.029]}\end{array}$ & $\begin{array}{c}0.140 * * \\
{[.025]}\end{array}$ \\
\hline $\begin{array}{l}\text { married male }(\mathrm{MM}) \\
\qquad \mathrm{N}=1,250\end{array}$ & $\begin{array}{c}0.056 * * \\
{[.016]}\end{array}$ & $\begin{array}{c}-0.384 * * \\
{[.065]}\end{array}$ & $\begin{array}{l}0.049 * \\
{[.021]}\end{array}$ & $\begin{array}{c}0.191 * * \\
{[.064]}\end{array}$ & $\begin{array}{c}0.086 * * \\
{[.021]}\end{array}$ & $\begin{array}{c}0.446 * * \\
{[.021]}\end{array}$ \\
\hline $\begin{array}{l}\text { single female (SF) } \\
\qquad \mathrm{N}=3,852\end{array}$ & $\begin{array}{l}-0.008 \\
{[.011]}\end{array}$ & $\begin{array}{c}0.148 * * \\
{[.047]}\end{array}$ & $\begin{array}{c}-0.115^{* *} \\
{[.014]}\end{array}$ & $\begin{array}{c}-0.346^{* *} \\
{[.046]}\end{array}$ & $\begin{array}{c}0.039 * * \\
{[.015]}\end{array}$ & $\begin{array}{l}-0.001 \\
{[.013]}\end{array}$ \\
\hline $\begin{array}{l}\text { cohabiting female (CF) } \\
\quad \mathrm{N}=654\end{array}$ & $\begin{array}{l}0.002 \\
{[.020]}\end{array}$ & $\begin{array}{l}0.120 \\
{[.087]}\end{array}$ & $\begin{array}{l}0.003 \\
{[.027]}\end{array}$ & $\begin{array}{l}-0.088 \\
{[.086]}\end{array}$ & $\begin{array}{c}0.075 * * \\
{[.029]}\end{array}$ & $\begin{array}{c}0.123 * * \\
{[.024]}\end{array}$ \\
\hline $\begin{array}{l}\text { married female }(\mathrm{MF}) \\
\qquad \mathrm{N}=967\end{array}$ & $\begin{array}{l}0.008 \\
{[.017]}\end{array}$ & $\begin{array}{l}-0.052 \\
{[.076]}\end{array}$ & $\begin{array}{l}-0.017 \\
{[.023]}\end{array}$ & $\begin{array}{l}-0.113 \\
{[.075]}\end{array}$ & $\begin{array}{l}0.062 * \\
{[.025]}\end{array}$ & $\begin{array}{c}0.378 * * \\
{[.023]}\end{array}$ \\
\hline $\mathrm{H}_{0}: \mathrm{CM}=\mathrm{MM}$ & & $* *$ & & & $*$ & $* *$ \\
\hline $\mathrm{H}_{0}: \mathrm{SF}=\mathrm{CF}$ & & & $* *$ & $* *$ & & $* *$ \\
\hline $\mathrm{H}_{0}: \mathrm{CF}=\mathrm{MF}$ & & & & & & $* *$ \\
\hline $\mathrm{H}_{0}: \mathrm{SF}=\mathrm{MF}$ & & $* *$ & $* *$ & $* *$ & & $* *$ \\
\hline $\begin{array}{l}\text { estimation } \\
\text { method }\end{array}$ & Logit & OLS & Logit & OLS & Logit & Logit \\
\hline $\mathrm{N}$ & 11,387 & 6,706 & 6,585 & 6,585 & 6,364 & 6,595 \\
\hline
\end{tabular}

Notes: Same as table 6. 
Appendix Table 2. Differences in other outcomes by gender and marital/cohabitation status.

\begin{tabular}{|c|c|c|c|c|c|}
\hline & $\begin{array}{c}(1) \\
\text { Graduated }\end{array}$ & Time to degree & $\begin{array}{l}\text { (3) } \\
\text { Published while in } \\
\text { school }\end{array}$ & $\begin{array}{c}\text { (4) } \\
\text { Number of } \\
\text { publications }\end{array}$ & $\begin{array}{c}(5) \\
\text { Tenure track job } \\
\text { at } 6 \text { months }\end{array}$ \\
\hline $\begin{array}{l}\text { single male }(\mathrm{SM}) \\
\mathrm{N}=4,664\end{array}$ & -- & -- & -- & -- & -- \\
\hline $\begin{array}{l}\text { married male, no children (MM) } \\
\qquad \mathrm{N}=863\end{array}$ & $\begin{array}{l}0.059 * \\
{[.025]}\end{array}$ & $\begin{array}{c}-0.399 * * \\
{[.107]}\end{array}$ & $\begin{array}{l}0.031 \\
{[.034]}\end{array}$ & $\begin{array}{l}0.135 \\
{[.106]}\end{array}$ & $\begin{array}{l}0.041 \\
{[.034]}\end{array}$ \\
\hline $\begin{array}{l}\text { married male, with children (MMC) } \\
\quad \mathrm{N}=387\end{array}$ & $\begin{array}{c}0.050 * * \\
{[.017]}\end{array}$ & $\begin{array}{c}-0.364 * * \\
{[.073]}\end{array}$ & $\begin{array}{l}0.045 * \\
{[.023]}\end{array}$ & $\begin{array}{c}0.190 * * \\
{[.071]}\end{array}$ & $\begin{array}{c}0.099 * * \\
{[.023]}\end{array}$ \\
\hline $\begin{array}{l}\text { single female (SF) } \\
\qquad \mathrm{N}=4,506\end{array}$ & $\begin{array}{l}-0.011 \\
{[.010]}\end{array}$ & $\begin{array}{c}0.153 * * \\
{[.044]}\end{array}$ & $\begin{array}{c}-0.105^{* *} \\
{[.013]}\end{array}$ & $\begin{array}{c}-0.328 * * \\
{[.043]}\end{array}$ & $\begin{array}{c}0.042 * * \\
{[.014]}\end{array}$ \\
\hline $\begin{array}{l}\text { married female, no children (MF) } \\
\quad \mathrm{N}=715\end{array}$ & $\begin{array}{l}0.030 \\
{[.031]}\end{array}$ & $\begin{array}{l}-0.017 \\
{[.138]}\end{array}$ & $\begin{array}{l}-0.012 \\
{[.042]}\end{array}$ & $\begin{array}{l}-0.013 \\
{[.135]}\end{array}$ & $\begin{array}{l}0.028 \\
{[.045]}\end{array}$ \\
\hline $\begin{array}{l}\text { married female, with children (MFC) } \\
\qquad \mathrm{N}=252\end{array}$ & $\begin{array}{l}-0.004 \\
{[.019]}\end{array}$ & $\begin{array}{l}-0.052 \\
{[.083]}\end{array}$ & $\begin{array}{l}-0.030 \\
{[.025]}\end{array}$ & $\begin{array}{c}-0.176 * \\
{[.082]}\end{array}$ & $\begin{array}{l}0.065 * \\
{[.027]}\end{array}$ \\
\hline \multicolumn{6}{|l|}{$\mathrm{H}_{0}: \mathrm{MM}=\mathrm{MMC}$} \\
\hline $\mathrm{H}_{0}: \mathrm{SF}=\mathrm{MF}$ & & $*$ & $* *$ & & \\
\hline \multicolumn{6}{|l|}{$\mathrm{H}_{0}: \mathrm{MF}=\mathrm{MFC}$} \\
\hline $\mathrm{H}_{0}: \mathrm{SF}=\mathrm{MFC}$ & & & $*$ & $*$ & \\
\hline estimation method & Logit & OLS & Logit & OLS & Logit \\
\hline $\mathrm{N}$ & 11,387 & 6,706 & 6,585 & 6,585 & 6,364 \\
\hline
\end{tabular}

Notes: Same as table 6. 